\title{
Democracy in its Essence: Hans Kelsen as a Political Thinker
}

Sara Lagi

Lanham, MD (2020): Lexington Books, 204 pp.

\section{Robert Schuett}

University of Salzburg

E-Mail: robert.schuett@sbg.ac.at
Democracy in its Essence: Hans Kelsen as a Political Thinker takes the reader on a journey through the pen and practice of Kelsen, all the way back to the political struggles of the I920s to the mid-I950s, thereby making a thoughtful contribution to the burgeoning literature that re-visits Kelsen in so many different ways.

From Sara Lagi, a historian of political thought, we learn that one methodological way of reconstructing Kelsen's theory of democracy for our time is through its reference to the specific political context - Fascism, Bolshevism, the Cold War - in which he developed and sharpened his political thinking. What's more, Lagi makes the case that Kelsen's concept of democracy, understood in terms of pluralism, constitutionalism, relativism, and proceduralism, is not the offspring of some sort of naive formalism (as the Schmittians would have us believe) but that it is instead a realistic reaction to the political challenges of his time and the power struggles as he saw them play out in all political communities: past, present, and future.

This kind of political realism, as Lagi identifies in Kelsen's legal theory and political thinking, is presented in four concise chapters. While the book's short introduction speaks to how Kelsen has been explored in the Continental context, while remaining relatively neglected in the English-speaking world, Chapter I makes it clear that Kelsen's theory of democracy roots in the reality of a plurality of interests and values, which is a political realism of a kind that just can never be wished away; there's no harmony of interests, and to think otherwise is naïve.

Chapter 2 re-visits the Kelsen-Schmitt debate on constitutional jurisdiction, showing that these two fig- ures had very different views of what democracy is, and why that is. In Lagi's account of this legal and political battle, which was not only about constitutional law but about broader questions of government organization and the distribution of power within the democratic state, she shows how the Nazi jurist Carl Schmitt placed his faith in a strong executive as guardian of the constitution; by contrast, Kelsen argued for a judicialized constitutional enforcement mechanism. The key takeaway is Lagi's insistence on just how much or how deeply Kelsenian democracy is inextricably interconnected with the notion of having a properly independent constitutional court as the principal enforcer of the constitution. Chapter 3 argues that, to Kelsen, relativism has absolutely nothing to do with moral or epistemological indifference. It rather relates to the question, or virtue, of personal moral responsibility for one's thought and action; the idea that there are no moral absolutes is the very foundation of democracy, not its inherent defect.

To round off the book, Chapter 4 looks at how Kelsen conceived of democracy as a most efficacious procedure of arriving at political decisions in political communities. By this point, Lagi has brought the reader to what was Kelsen's new home, the United States; and her understanding of the jurist's massive 1955 essay, Foundations of Democracy (rooted in his Walgreen Lectures at Chicago), makes one thing clear: Kelsen the realist was very much aware that any realist form of government, i.e., democracy, has but one task: to protect You and Me from the many faces of the abuse of power. In other words, what Lagi's timely book does is offer - through Kelsen - a timeless defence of liberal democracy. 
Lagi's case for Kelsen as a realistic political thinker and realistic theorist of democracy is bold and methodologically sound. Readers will not be pleased with the occasional typos, but that's minor. Democracy in its Essence: Hans Kelsen as a Political Thinker is an important book-length study of why Kelsen deserves to be re-read in the twenty-first century.

Where there is so much Schmitt in today's politics and international relations (see Scheuerman 202I), re-visiting Kelsen's struggle for democracy and open society ideals is important because it helps us understand why we've been there before, what the real dangers are, and how we might get out of this alive. And with a view to normative international relations theory, Lagi's book is well-timed background reading for what the sociologist and ideology critic Irving Louis Horowitz (2006), writing in The National Interest, suggested years ago: To have foreign policy be guided by democratic values means to have a clear view of what democracy really is; and any such normative discussion about the nature of democracy should certainly include "Hans Kelsen."

If Hans J. Morgenthau, leading mid-twentieth century political realist, were still alive, he too would most probably say: read Kelsen!

\section{References}

Horowitz, Irving Louis (2006), The Struggle for Democracy, in: The National Interest, or.03.2006, Internet: https://nationalinterest.org/article/the-strugglefor-democracy-880 (access: 29.03.202I).

Kelsen, Hans (1955), Foundations of Democracy, Ethics, Vol. 66(I), I-IOI.

Scheuerman, William E. (202I), 'Carl Schmitt's Comeback?' Understanding Trump and Global Authoritarianism, in: Public Seminar, 17.02.2021, Internet: https:// publicseminar.org/essays/carl-schmitts-comeback/ (access: 17.04.2021). 